\title{
Article
}

\section{Percentage dose reductions}

Davies, Janice Anne

Available at http://clok.uclan.ac.uk/27850/

Davies, Janice Anne (2019) Percentage dose reductions. Journal of Prescribing Practice, 1 (3). p. 122. ISSN 2631-8385

It is advisable to refer to the publisher's version if you intend to cite from the work.

10.12968/jprp.2019.1.3.122

For more information about UCLan's research in this area go to

http://www.uclan.ac.uk/researchgroups/ and search for < name of research Group>.

For information about Research generally at UCLan please go to http://www.uclan.ac.uk/research/

All outputs in CLoK are protected by Intellectual Property Rights law, including Copyright law. Copyright, IPR and Moral Rights for the works on this site are retained by the individual authors and/or other copyright owners. Terms and conditions for use of this material are defined in the policies page.

\section{CLoK}

Central Lancashire online Knowledge www.clok.uclan.ac.uk

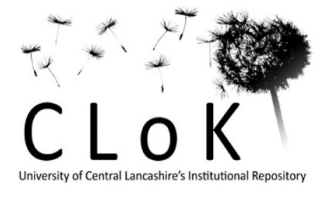


When calculating the dose of medicine for a patient it may be necessary to carry out a dose reduction, for example if they have co-morbidities such as renal impairment or liver impairment.

Try the following exercises that involve percentage dose reductions:

1. The normal dose of medicine $A$ is $300 \mathrm{mg}$ daily. If the dose is reduced by $25 \%$ what dose should be prescribed? $225 \mathrm{mg}$

2. The normal dose of medicine $B$ is $300 \mathrm{mg}$ daily. If the dose needs to be reduced to $25 \%$ of the original dose what dose should be prescribed? $75 \mathrm{mg}$

3. The normal dose of medicine $C$ is $1 \times 100 \mathrm{mg}$ capsule three times a day. If the dose is reduced by one-third what dose should be prescribed? $100 \mathrm{mg}$ twice a day

4. The normal dose of medicine $D$ is $80 \mathrm{mg}$ daily. The dose needs to be reduced by $50 \%$ to accommodate a drug interaction. What dose should be prescribed? $40 \mathrm{mg}$

5. The normal dose of medicine $\mathrm{E}$ is $200 \mathrm{mg}$ daily. The dose is to be reduced to $75 \%$. What dose should be prescribed? $150 \mathrm{mg}$

Now try these percentage reduction calculations which are based on BNF dosage advice (RPS\&BMA, 2019):

Metronidazole adult dose in anaerobic infections is $400 \mathrm{mg}$ three times a day orally for 7 days. In severe liver disease the total daily dose should be reduced to one-third, and given once daily.

6. What dose should be prescribed? $400 \mathrm{mg}$ once daily

Digoxin adult dose to treat heart failure (for patients in sinus rhythm) is $62.5-125$ micrograms orally once daily,

The manufacturer advises to reduce the dose by half with concurrent use of amiodarone, dronedarone and quinine.

7. What dose range should be considered for prescribing for a patient taking concurrent amiodarone? 31.25-62.5micrograms

The BNF advises that when switching from intravenous to oral route the dose may need to be increased by $20-33 \%$ to maintain the same plasma-digoxin concentration.

8. If an IV dose of 62.5 micrograms has been given, calculate what oral dose should be considered if the dose was increased by $20 \% 75$ micrograms 
Percentages are also used when considering the benefits of treatment, for example reduction in risk of stroke with anticoagulation. Anticoagulation in patients with Atrial Fibrillation reduces the risk of stroke by approx. 69\% (NICE, 2014)

9. Out of 1000 patients with a CHA2DS2-VASc score of 4 and no anticoagulant, 55 of them will have a stroke.

How many strokes will be avoided if they are all anticoagulated? 38

Out of 1000 patients with a CHA2DS2-VASc score of 2 and no anticoagulant, 25 of them will have a stroke.

10. How many strokes will be avoided if they are all anticoagulated? 17

\section{$\underline{\text { References }}$}

Royal Pharmaceutical Scoiety (RPS) \& British Medical Association (BMA) 2019, British National Formulary 76. Pharmaceutical Press, London.

National Institute of Health and Care Excellence (2014) Patient Decision Aid - Atrial fibrillation: medicines to help reduce your risk of a stroke - what are the options? 